$\xi=-$ 国

\title{
Impact of News Sentiment Analysis on Market Price Movement During the Dividend Period
}

\author{
W. L. Hor*, W. X. Goh, S. H. Ow \\ Department of Software Engineering, Faculty of Computer Science and Information Technology, University of Malaya, 50603 Kuala \\ Lumpur, Wilayah Persekutuan, Malaysia \\ *Corresponding author E-mail: horwengliang@um.edu.my
}

\begin{abstract}
This study presents development of a system for analysing the polarity of stock market news to guide traders in making better decision when buying, selling or holding stocks during the dividend period. It will also help traders by reducing the risk of making inaccurate decision in trading. Trusted and reliable data such as dividend news, daily share market price, company news and announcements from Bursa Malaysia and The Edge Market will be used for performing news sentiment analysis using Azure Text Analytics. The results show that company news and announcements do not have significant effect on the Malaysia stock prices as the prices move within the range of $0-1 \%$, which is the benchmark of the normal range of daily price movement.
\end{abstract}

Keywords: Stock Market; News Sentiment Analysis; Dividend; Bursa Malaysia.

\section{Introduction}

Listed companies in the Bursa Malaysia, which had made good profits often give out good dividends to their shareholders. There are four major dates when a listed company announces its dividend - dividend announcement date, ex-date (ex-dividend date), entitlement date, and payment date. Ex-date is the date on or after which a share is traded without a previously declared dividend, i.e., the seller and not the buyer will be entitled to the recently announced dividend. During this dividend entitlement period (from the announcement date to the payment date), the share price of a company could rise or fall below the share price on the dividend news announcement date, or the price when the shareholders first bought that company's shares [1]. Hence, in the case of a good dividend of 21 cents, it is difficult for the shareholders to determine and decide when is the most "profitable" time to 1) sell their shares (before ex-date), or 2) hold their shares to receive the dividend first before selling (sell after the ex-date), or 3 ) buy more shares before the ex-date. If the price rises after the ex-date, shareholders who have chosen option 3 will make the most profit, but those who have chosen option 1 will not make any profit. In this regard, sentiment analysis has become a useful guide to help shareholders and active traders in their share trading decisionmaking.

Shareholders and traders can use sentiment analysis to evaluate a company's performance as well as its business success. Some traders believe that the more the positivity in sentiment, one should purchase more stocks/shares and vice versa as shown in Fig. 1 [2]. Active traders find it necessary to track sentiment if they trade in a large number of companies. However, keeping up with the news for all the companies is very difficult. This research focuses on news sentiment analysis during the dividend announcement period when all the news are crowdsourced. The stock price will be predicted using machine learning to learn the trend of the stock price and the news sentiments. It is also based on the premise that stock price correlates with the polarity accumulated from multiple news between the dividend announcement date and payment date, whereby positive sentiment will result in stock price increase and vice versa.

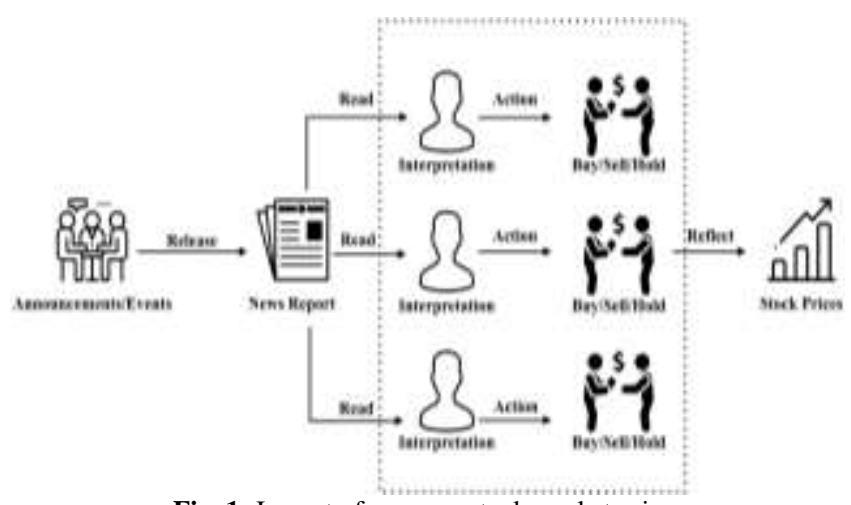

Fig. 1: Impact of news on stock market prices

\section{Literature Review}

There are four main factors that influence a company in its dividend policy - company earnings, debt size, investments, and largest shareholder. In [3] indicated that higher dividends announced by a company in Malaysia would mean that the company is large and earns good profits. This means that a big shareholder owns a greater percentage of the shares, resulting in having higher investment opportunities and low debt, and thus more likely to pay higher dividend to the shareholders. In [4] used event methodology to explore the reaction of the stock price to the dividend announcement date. The study reported that declaring higher percentage of dividend does not mean that traders will get higher payment during the payment date as an abnormal return could happen during the dividend payment period. 
In [5] used dual sentiment analysis to overcome the snag polarity shifting problem, which has been defined as the definite solution to bring both the original sentiment and the reverse of the original sentiment for predicting the stock price. In their study on sentiment analysis, in [6] proposed a contextual entropy model to expand a set of seed words by discovering similar emotion words and their corresponding intensities from online stock market news articles. The findings showed positive result and improvement in the sentiment classification of stock market news.

Crowdsourced data for stock market news such as Tweets [7] can improve the experimental result. This is because Twitter can produce large amount of data that can be used in the training model to analyse text sentiments and hence, increase the accuracy of text classification.

In [8] conducted a research on sentiment analysis of financial texts and published a list which consists of both "Positive" and "Negative" words which are financial specific. In [9] also produced another list of "Positive" and "Negative" words for general cases. Both lists have been used as main references for stock market sentiment analysis.

Apart from news or announcements which have been identified as one of the parameters that can affect the ups and downs of the stock market, technical analysis is another main factor that can be used to determine the patterns of historical prices for forecasting the stock price [10].

In [11] divided their study into two stages. In the first stage, they proposed a simple strategy to generate a few high-quality sentiment and topic seeds for the target domain. In the second stage, they proposed a novel Relational Adaptive Bootstrapping (RAB) method to expand the seeds, in order to exploit the relationship between the topic and opinion words, and also to make use of part of useful source domain labeled data.

In [12] studied the polarity-bearing topics extracted by JointSentiment-Topic (JST). They found that by augmenting the original feature space with polarity-bearing topics, the in-domain supervised classifiers learned from the augmented feature representation achieved the best performance of $95 \%$ on the movie review data and an average of $90 \%$ on the multi-domain sentiment dataset. Table 1 shows a summary of the studies reviewed.

Table 1: Summary of literature review: Stock market dividend, sentiment analysis and news.

\begin{tabular}{|c|c|c|c|}
\hline References & $\begin{array}{c}\text { Main Fo- } \\
\text { cus/Issue(s) }\end{array}$ & Strengths & Weaknesses \\
\hline [3] & $\begin{array}{l}\text { Study factors that } \\
\text { affect dividend } \\
\text { policy of public } \\
\text { listed firms in } \\
\text { Malaysia. }\end{array}$ & $\begin{array}{l}\text { Useful input on } \\
\text { how dividend } \\
\text { policy is formu- } \\
\text { lated and revised. }\end{array}$ & $\begin{array}{l}\text { Only focuses on } \\
\text { Malaysian listed } \\
\text { companies with } \\
\text { high market } \\
\text { capitalization. }\end{array}$ \\
\hline [4] & $\begin{array}{l}\text { Study market } \\
\text { reaction to divi- } \\
\text { dend announce- } \\
\text { ment using event } \\
\text { methodology. }\end{array}$ & $\begin{array}{l}\text { Proven dividend } \\
\text { signaling theory } \\
\text { that dividend } \\
\text { announcement } \\
\text { can have signifi- } \\
\text { cant impact on } \\
\text { share price. }\end{array}$ & $\begin{array}{l}\text { Does not set any } \\
\text { benchmark on } \\
\text { choosing com- } \\
\text { pany sector. } \\
\text { There might be } \\
\text { bias in choosing } \\
\text { a company. }\end{array}$ \\
\hline [5] & $\begin{array}{l}\text { Using dual sen- } \\
\text { timent analysis to } \\
\text { overcome snag } \\
\text { polarity shifting } \\
\text { problem. }\end{array}$ & $\begin{array}{l}\text { Used dual senti- } \\
\text { ment classifier } \\
\text { where feature } \\
\text { selection is an } \\
\text { extricating fea- } \\
\text { ture from the } \\
\text { corpus which } \\
\text { aids in modelling } \\
\text { classifier. }\end{array}$ & $\begin{array}{l}\text { The sources of } \\
\text { information is } \\
\text { increasing on } \\
\text { daily basis } \\
\text { making it diffi- } \\
\text { cult to retrieve } \\
\text { all required } \\
\text { information. }\end{array}$ \\
\hline [6] & $\begin{array}{l}\text { Use contextual } \\
\text { entropy model to } \\
\text { expand emotion } \\
\text { words and their } \\
\text { intensity for the } \\
\text { sentiment classi- } \\
\text { fication. }\end{array}$ & $\begin{array}{l}\text { This model } \\
\text { measures the } \\
\text { similarity be- } \\
\text { tween two words } \\
\text { by comparing the } \\
\text { contextual distri- } \\
\text { butions to show } \\
\text { improvement to }\end{array}$ & $\begin{array}{l}\text { The emotion } \\
\text { word does not } \\
\text { specify whether } \\
\text { the word be- } \\
\text { longs to a com- } \\
\text { pany or to the } \\
\text { whole market. }\end{array}$ \\
\hline
\end{tabular}

\begin{tabular}{|c|c|c|c|}
\hline References & $\begin{array}{l}\text { Main Fo- } \\
\text { cus/Issue(s) }\end{array}$ & Strengths & Weaknesses \\
\hline & & $\begin{array}{l}\text { the classification } \\
\text { process. }\end{array}$ & \\
\hline [7] & $\begin{array}{l}\text { Analysing senti- } \\
\text { ment using } \\
\text { crowdsourced } \\
\text { data from Twit- } \\
\text { ter. }\end{array}$ & $\begin{array}{l}\text { The amount of } \\
\text { news and traders } \\
\text { analysis obtained } \\
\text { from Twitter is } \\
\text { greater than the } \\
\text { amount obtained } \\
\text { from any stock } \\
\text { market news } \\
\text { vendor. }\end{array}$ & $\begin{array}{l}\text { Comments by } \\
\text { traders in Twit- } \\
\text { ter are not relia- } \\
\text { ble. }\end{array}$ \\
\hline [8] & $\begin{array}{l}\text { Creating a list of } \\
\text { financial-specific } \\
\text { texts. }\end{array}$ & $\begin{array}{l}\text { The list of words } \\
\text { appropriate for } \\
\text { defining both the } \\
\text { positive and } \\
\text { negative senti- } \\
\text { ments in finan- } \\
\text { cial-specific } \\
\text { context. }\end{array}$ & $\begin{array}{l}\text { The list of } \\
\text { words has to be } \\
\text { reviewed from } \\
\text { time to time so } \\
\text { that changes in } \\
\text { financial- } \\
\text { specific text can } \\
\text { be updated. }\end{array}$ \\
\hline [9] & $\begin{array}{l}\text { Creating a list of } \\
\text { positive and } \\
\text { negative opinion } \\
\text { words in general } \\
\text { case. }\end{array}$ & $\begin{array}{l}\text { The list of words } \\
\text { is useful when } \\
\text { analyzing com- } \\
\text { ments from trad- } \\
\text { ers or stock } \\
\text { analysts. }\end{array}$ & $\begin{array}{l}\text { The list of } \\
\text { words needs to } \\
\text { be revised from } \\
\text { time to time to } \\
\text { maintain its } \\
\text { relevancy. }\end{array}$ \\
\hline [10] & $\begin{array}{l}\text { Focus on both } \\
\text { technical analysis } \\
\text { and public sen- } \\
\text { timent to predict } \\
\text { the stock market. }\end{array}$ & $\begin{array}{l}\text { Covers wider } \\
\text { range of parame- } \\
\text { ters on predicting } \\
\text { stock market } \\
\text { prices as it in- } \\
\text { cludes important } \\
\text { parameters such } \\
\text { as technical } \\
\text { analysis with } \\
\text { public sentiment. }\end{array}$ & $\begin{array}{lr}\text { Conducts } & \text { only } \\
\text { simple senti- } \\
\text { ment analysis } \\
\text { (scoring by } \\
\text { counting posi- } \\
\text { tive and nega- } \\
\text { tive words from } \\
\text { pre-specified } \\
\text { lists) which does } \\
\text { not extract } \\
\text { useful infor- } \\
\text { mation from the } \\
\text { news articles. }\end{array}$ \\
\hline [11] & $\begin{array}{l}\text { Study domain } \\
\text { adaptation } \\
\text { framework for } \\
\text { sentiment and } \\
\text { topic lexicon co- } \\
\text { extraction in a } \\
\text { domain of inter- } \\
\text { est. }\end{array}$ & $\begin{array}{l}\text { Supervised learn- } \\
\text { ing methods rely } \\
\text { heavily on man- } \\
\text { ually labeled } \\
\text { training data, and } \\
\text { use two-fold } \\
\text { framework that } \\
\text { does not require } \\
\text { any labeled data, } \\
\text { but has lots of } \\
\text { labeled data in } \\
\text { another related } \\
\text { domain. }\end{array}$ & $\begin{array}{l}\text { Focuses on } \\
\text { heterogeneous } \\
\text { relationship } \\
\text { between topic } \\
\text { and sentiment } \\
\text { words. }\end{array}$ \\
\hline [12] & $\begin{array}{l}\text { Modifying JST } \\
\text { model by incor- } \\
\text { porating word } \\
\text { polarity priors } \\
\text { through modify- } \\
\text { ing the topic- } \\
\text { word Dirichlet } \\
\text { priors. }\end{array}$ & $\begin{array}{l}\text { Feature augmen- } \\
\text { tation and selec- } \\
\text { tion based on the } \\
\text { information gain } \\
\text { criteria for cross- } \\
\text { domain senti- } \\
\text { ment classifica- } \\
\text { tion which is } \\
\text { much simpler } \\
\text { and does not } \\
\text { require difficult } \\
\text { parameter tuning. }\end{array}$ & $\begin{array}{l}\text { The JST model } \\
\text { does not appear } \\
\text { to be effective } \\
\text { when it is added } \\
\text { pseudo- labeled } \\
\text { examples. }\end{array}$ \\
\hline
\end{tabular}

Based on past studies, more listed companies in Malaysia in terms of different market capitalization must be considered to gain an indepth understanding of the dividend policy, and the effect of dividend announcement on share market price. The announcement of dividend is one parameter that needs to be considered when hypothesising that company news and announcements during dividend period can affect the stock price during dividend payout.

One important finding is that data obtained from Twitter is not reliable and may be biased which could affect the study outcome. Hence, the data source should first be examined in order to con- 
firm the reliability and integrity of the data to avoid any bias which could invalidate the study.

The articles reviewed also show that the most reliable data would be the news and announcements released by the companies themselves. Previous researchers have highlighted some methods which could be used for achieving accurate sentiment analysis. These include using dual sentiment classifier, contextual entropy model, supervised learning method in sentiment framework, and the JST model for cross-domain sentiment classification. However, most of the methods do not emphasize the use of company news or announcements from the financial sector. They focus more on the public opinion text and other domains that are not related to the financial sector. The type of words that are used in public opinions may differ from the words that are used in writing a company's news and announcements. Hence, methods that have been used in past researches are suitable for analyzing sentiments expressed in public but not a company's official news or announcements. Thus, it is important that the models, classifier or even the supervised learning sentiment classification should focus on both public opinions as well as official news to ensure higher accuracy in predicting financial stock price movement. This is because any inaccuracy in stock market prediction could cause shareholders and traders to suffer loss and lose confidence in the stock market.

\section{Methodology}

Based on literature review, the research problems pertaining to the analysis of news sentiment and its impact were identified. This study proposes an approach in dividend news sentiment analysis to help the shareholders and traders in making better trading decision during the dividend period. Fig. 2 shows the three research phases, and the activities and tools used to achieve the research objective.

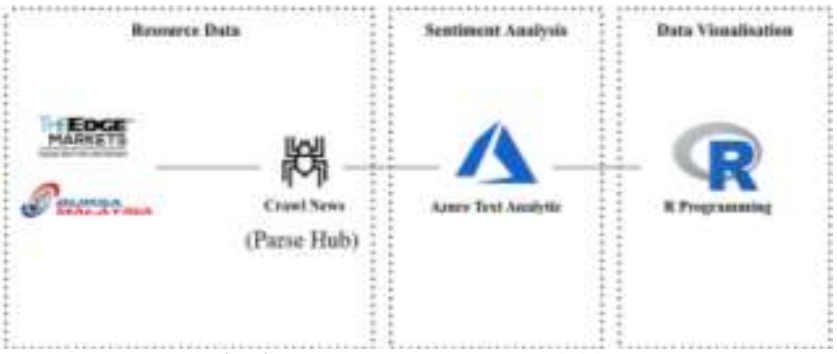

Fig. 2: Research phases and activities

The first phase is sourcing the data which involves crawling stock market news from reliable sources using Parse Hub [13]. In the second phase, raw data is processed to clean or remove extraneous data (words) using a simple program (function). Azure Text Analytics tool is then used to perform sentiment analysis and to analyse the relationship between the sentiment score and the stock price. The third phase is data visualization to present the outcomes of sentiment analysis using R Studio.

\subsection{Dataset}

In this study, four main datasets are used:

[1] A list of KLSE historical stock prices with the entitlement of dividend records from 2012 to 2017 (six years data). Data of the historical prices consist of the open, close, lowest and highest prices for each trading.

[2] Company announcements (Number of dividend) from 10 companies of the Trading/Services sector that are listed at the main board of Bursa Malaysia, as shown in Table 2.

[3] Ten companies from Bursa Malaysia which have capital market value of Ringgit Malaysia one billion and above will be used for analysis. This is to ensure that the companies have proven track record in running a business and had gen- erated large revenue to afford dividend payout, from 2012 to 2017 , and the consistency of obtaining data such as company news [14].

[4] Four important dates during the dividend period - announcement date, ex-date, entitlement date, and payment date. Dividend percentage or dividend in cent is also recorded from 2012 to 2017.

[5] News articles written in English retrieved from The Edge Market, a major financial news publication in Malaysia. Each piece of news is time-stamped indicating the date of release, and this helps in analyzing the news by date.

Table 2: Ten listed companies at main board of Bursa Malaysia (Trading/Services Sector, 2012-2017)

\begin{tabular}{|c|c|c|}
\hline Stock Code & Company & Market Capital (RM) \\
\hline 6599 & AEON Co. (M) Berhad & $3.201 \mathrm{~b}$ \\
\hline 5218 & Sapura Energy Berhad & $3.775 \mathrm{~b}$ \\
\hline 4197 & SIME Darby Berhad & $16.594 \mathrm{~b}$ \\
\hline 4677 & YTL Corporation Berhad & $12.220 \mathrm{~b}$ \\
\hline 5209 & Gas Malaysia Berhad & $3.685 \mathrm{~b}$ \\
\hline 7048 & Atlan Holdings Bhd. & $1.139 \mathrm{~b}$ \\
\hline 3395 & Berjaya Co. Bhd. & $1.452 \mathrm{~b}$ \\
\hline 4634 & POS Malaysia Bhd. & $3.115 \mathrm{~b}$ \\
\hline 5099 & AirAsia Group Bhd. & $10.193 \mathrm{~b}$ \\
\hline 6399 & Astro Malaysia Holdings Bhd. & $8.290 \mathrm{~b}$ \\
\hline
\end{tabular}

\subsection{Preprocessing of Data/Text}

The data obtained from the various sources were preprocessed to ensure integrity, consistency, and reliability. Data pre-processing was carried out using the following steps:

A Web scrapping tool is used to scrap company news and announcements from the Bursa Malaysia Website as no API endpoints are provided by the Bursa Malaysia platform. The long list of scrapped data was first filtered based on the date of dividend period recorded from 2012 to 2017. Only news and announcements that were released within the dividend period (from announcement date to payment date) are used for analyzing sentiment and calculating the scores. Common words such as I, a, the, you, we, were, am, and us are first removed before proceeding to the text pre-processing steps, as illustrated in Fig. 3 and Fig. 4.

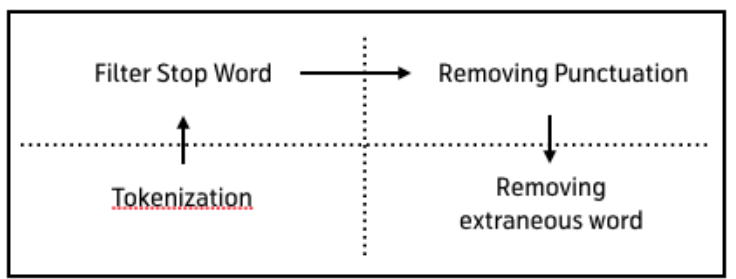

Fig. 3: Text pre-processing before sentiment analysis

In Fig. 3, the words in a sentence are tokenized, and this is followed by filtering the list of 'stop words', as shown in Fig. 4. These stop words together with punctuation marks will be removed to avoid inaccuracy during sentiment analysis. Extraneous words that are not related to the news subject are also removed before performing sentiment analysis. Fig. 5 illustrates the removal of 'stop words' (words that are boxed) in the company (Astro) news.

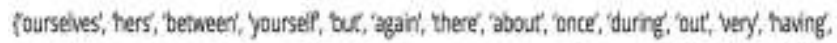

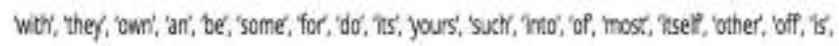

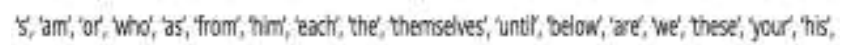
throught, 'dar', nor, 'me', were, her, 'more', himset, this', 'down, shoud', 'our', their, while',

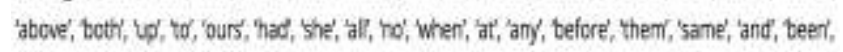

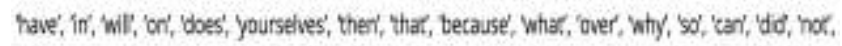
how, 'under, the, you', therser, has', fust, where, too', 'only, 'mysel, which, those, ", 'after, few,

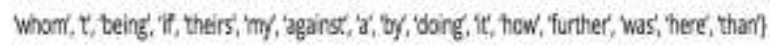

Fig. 4: List of 'stop words' 


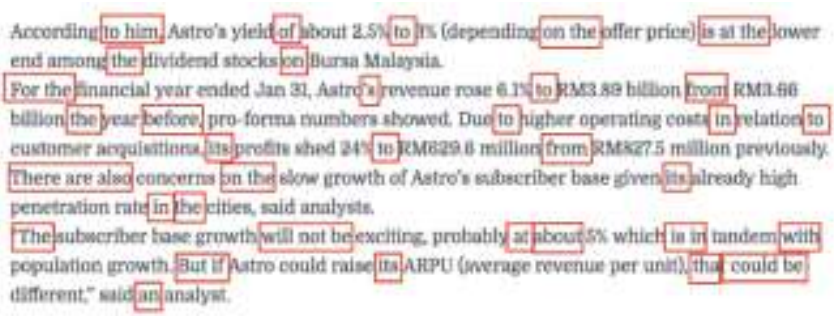

Fig. 5: Example: Removal of 'stop words' in the Astro news (The Edge Market, 2013)

\subsection{Sentiment Analysis}

Azure Text Analytics is chosen as the main sentiment analysis tool. This is because it has a scalable Natural Language Processing (NLP) feature that can analyze millions of documents to discover the insights (crucial facts) of the documents. Apart from that, it has a deep learning-based NLP to analyse text accurately. Azure Text Analytics models are pretrained for users and are also constantly trained with new data across multiple domains to improve accuracy. They used a large dataset of text records that had already been labeled with sentiment for each record. Azure Text Analytics uses Score Vowpal Wabbit Version 7-4 Model to generate scores for a set of input data, using an existing trained Vowpal Wabbit model [15]. The model produces a prediction score normalized from $0-1$. A score that is close to 1 indicates positive sentiment, while score close to 0 indicates negative sentiment. A score of 0.5 indicates the lack of sentiment, a neutral condition. The score obtained is converted into a percentage by multiplying it with $100 \%$. A score of $50 \%$ indicates neutral sentiment, i.e., the number of positive sentiments and negative sentiments are the same (balance sentiments). A score of oR 50\% indicates positive (POS) sentiment, i.e., the number of positive sentiments exceed the number of negative sentiments. Conversely, a score of less than $50 \%$ indicates negative (NEG) sentiment, i.e., the number of negative sentiments exceed positive sentiment. Fig. 6 shows an example of significant words in the company (Astro) news.

According to him Astrois yield of about $2.55103 \%$ (Eepending on the offer price) is at the lower end among the dividend stochs on Bursa Makyyin.

For the financal year ended lan 31. Astro's sevenue rose 3.15 to RM3,89 billion from RM3.88 billinn the year before, pro-forma numbers showed. Due to hlasher roperating costa in relation to

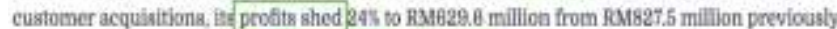
There are also concerns on the glow groweth of hatro's pubseriber base given its already high penerration ralt in the citiss, said amalysts.

The subscriter base growth will not be exciting, protably at about $5 \times$ which is in tandem with pogulation growith But is Astro gould reise is ARPU (merage revenue per unith, that could be different;" aid an analyne

Fig. 6: Significant words in the Astro news

\begin{tabular}{|c|c|c|}
\hline kn & Whest & 2 \\
\hline 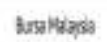 & ilocitar & 1 \\
\hline 1231 & tats & 1 \\
\hline
\end{tabular}

Fig. 7: Detecting entity in the Astro news

Azure Text Analytics can identify the significant entity in the news, for example, Astro news (Fig. 6). The word "Astro" will be classified as "Person" while "Jan 31" is detected as "Date". Entity that contain sentiment include: lower, rose, higher, profits, and slow growth.

A simple program was written to ease the word identification routine from the data obtained through Web crawling where the contents of the news or announcements will be uploaded to a server, and then sent to Azure Text Analytics through the API. Text preprocessing is then performed from this stage until the sentiment analysis process. The result will be produced in JSON format.
Another simple program is executed to convert the JSON format into a normal readable text paragraph, as shown in Fig. 7.

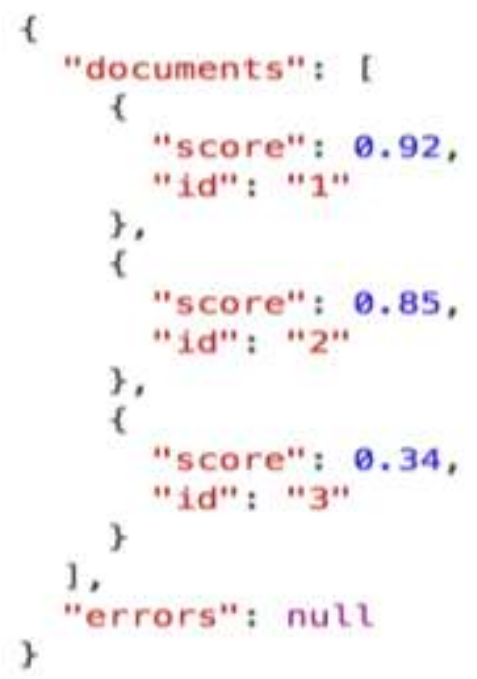

Fig. 7: JSON output of the sentiment score

The score is calculated using the model presented in section 3.3 above. Each score is converted into a percentage by multiplying it with $100 \%$ and is then used to determine the type of sentiment (positive, neutral, or negative).

\subsection{Classification of Sentiment}

There are three types of sentiments used in this research - Positive Neutral and Negative. Azure Text Analytics uses confidence level to determine the content's sentiment. The type of content sentiment will be determined based on the sentiment that has the highest confidence level during comparison. Table 3 shows the type of sentiment based on the score obtained using Azure Text Analytics on the sentiment content.

Table 3: Types of sentiment

\begin{tabular}{|c|c|}
\hline Type of Sentiment & Score \\
\hline Positive & More than $50 \%$ \\
\hline Neutral & $50 \%$ \\
\hline Negative & Less than $50 \%$ \\
\hline
\end{tabular}

\subsection{Benchmarking the Sentiment Analysis}

A healthy market is always subject to ups and downs. It neither goes one way up only nor one way down only. Hence, this poses the question: "How are we going to set the benchmark for positive or negative sentiment news that can truly affect the rise and fall of the stock price?" in [2] studied the impact of dividend announcement on stock return, and found a positive incidence of abnormal return about two days post-announcement. The study also reported that there is increasing tendency in the post-event period (after dividend news announcement period) which is significant at $1 \%$ level. Based on this research finding, the impact of news sentiment, is therefore, benchmarked at price movement of more than $1 \%$, showing the after-effect of the news and announcements released by the company. Alternatively, when a company releases news or announcements where its stock price movement is much higher compared to that of other companies in the same sector, there is direct correlation between news sentiment and the price [16]. Thus, during the process of data analysis, the relationship between the effect of news sentiment and stock price must be considered.

\section{Results and Discussion}

For this study, a company, Sime Darby Sdn. Bhd. (4197) was chosen to illustrate the types of sentiment during the dividend 
period from 3 Nov 2013 until 24 Jan 2014 and a payout dividend of 27 cents as shown in Table 4 .

Table 4: Sime Darby 2013 Financial Year (Dividend)

Announcement Date

\begin{tabular}{|c|c|}
\hline Announcement Date & $03 / 11 / 2013$ \\
\hline Ex-Date & $23 / 12 / 2013$ \\
\hline Entitlement Date & $26 / 12 / 2013$ \\
\hline Payment Date & $24 / 01 / 2014$ \\
\hline Dividend (cent) & 27.00 \\
\hline
\end{tabular}

Tables 5-7 show the sentiment and market trend for the three periods - from dividend announcement date to ex-date, ex-date to entitlement date, and entitlement date to payment date respectively.

Table 5: Sentiment and market trend: Announcement date to Ex-date (Sime Darby. Stock Code: 4197)

\begin{tabular}{|c|c|c|c|}
\hline Announcement Date & Sentiment & Close Price & Change (\%) \\
\hline $11 / 11 / 2013$ & Neutral (50\%) & 4.75 & \\
\hline $15 / 11 / 2013$ & Neutral (50\%) & 4.755 & 0.11 \\
\hline $18 / 11 / 2013$ & Neutral (50\%) & 4.785 & 0.63 \\
\hline $20 / 11 / 2013$ & Negative (30\%) & 4.845 & 1.25 \\
\hline $21 / 11 / 2013$ & Neutral (50\%) & 4.775 & -1.44 \\
\hline $26 / 11 / 2013$ & Neutral (50\%) & 4.815 & 0.84 \\
\hline $28 / 11 / 2013$ & Neutral (50\%) & 4.815 & 0 \\
\hline $29 / 11 / 2013$ & Positive (76\%) & 4.825 & 0.21 \\
\hline $02 / 12 / 2013$ & Neutral (50\%) & 4.825 & 0 \\
\hline $05 / 12 / 2013$ & Neutral (50\%) & 4.76 & -1.35 \\
\hline $11 / 12 / 2013$ & Neutral (50\%) & 4.83 & 1.47 \\
\hline $12 / 12 / 2013$ & Neutral (50\%) & 4.785 & -0.93 \\
\hline $13 / 12 / 2013$ & Negative (30\%) & 4.795 & 0.21 \\
\hline $16 / 12 / 2013$ & Neutral (50\%) & 4.785 & -0.21 \\
\hline $18 / 12 / 2013$ & Neutral (50\%) & 4.78 & -0.10 \\
\hline $20 / 12 / 2013$ & Negative (30\%) & 4.805 & 0.52 \\
\hline
\end{tabular}

Table 6: Sentiment and market trend: Ex-date and entitlement date (Sime Darby, Stock Code: 4197)

\begin{tabular}{|c|c|c|c|}
\hline Announcement Date & Sentiment & Close Price & Change (\%) \\
\hline $24 / 12 / 2013$ & Neutral (50\%) & 4.72 & \\
\hline $26 / 12 / 2013$ & Neutral (50\%) & 4.735 & 0.32 \\
\hline
\end{tabular}

Table 7: Sentiment and market trend: Entitlement date and payment date (Sime Darby, Stock Code: 4197)

\begin{tabular}{|c|c|c|c|}
\hline Announcement Date & Sentiment & Close Price & Change (\%) \\
\hline $15 / 01 / 2014$ & Neutral (50\%) & 4.605 & \\
\hline $20 / 01 / 2014$ & Negative (30\%) & 4.56 & -0.98 \\
\hline $24 / 01 / 2014$ & Neutral (50\%) & 4.525 & -0.77 \\
\hline
\end{tabular}

Based on the tables above, Sime Darby had shown significant reaction reflected by more than $1 \%$ market movement within the event day or the next day when there was a negative sentiment news or announcement. However, in the case of positive sentiment news or announcement, no significant reaction was observed as the market movement either remained the same or increased within $1 \%$. The percentage of variation for positive sentiment stayed within the range of the daily price movement as discussed in section 3.5, above. This situation could be due to the awareness of traders who could not be easily lured by the optimistic and flattering news reported by any parties or media. In fact, they will carry out technical and fundamental analysis in order to reaffirm their buying decision during positive sentiment. Traders would want to avoid any speculative trading that will cause price bubbles that sooner or later burst and cause asset price to decline [17]. However, based on the negativity that had been accumulated during the dividend period, the price of Sime Darby during the payout date was RM4.525, which was lower than the price RM4.75 at the time the dividend news was announced. This indicates that the accumulation of negative news is more than positive news during the dividend period. Shareholder or traders should sell their stocks before the dividend payment date in order to reduce loss in profit. Overall analyses of the 10 selected companies are also presented in this paper. Table 8 shows the number of dividends given out from 2012 to 2017 (6 years) by the 10 companies. Table 9 shows the overall sentiment analysis result during the dividend period from 2012 to 2017 ( 6 years) for the 10 companies. Table 10 shows the overall sentiment analysis for the three periods: between announcement date to Ex-date, Ex-date to entitlement date, and entitlement date to payment date for the 10 companies in the dividend period for the years from 2012 to 2017.

Table 8: Number of dividends from 2012 to 2017 (6 years, 10 companies)

\begin{tabular}{|c|c|c|}
\hline Stock Code & Company & Number of Dividend \\
\hline 6599 & AEON Co. (M) Berhad & 6 \\
\hline 5218 & Sapura Energy Berhad & 5 \\
\hline 4197 & SIME Darby Berhad & 13 \\
\hline 6742 & YTL Power International Berhad & 8 \\
\hline 5209 & Gas Malaysia Berhad & 15 \\
\hline 7048 & Atlan Holdings Bhd. & 19 \\
\hline 3395 & Berjaya Co. Bhd. & 4 \\
\hline 4634 & POS Malaysia Bhd. & 8 \\
\hline 5099 & AirAsia Group Bhd. & 7 \\
\hline 6399 & Astro Malaysia Holdings Bhd. & 27 \\
\hline
\end{tabular}

Table 9: Overall sentiment analysis during dividend period (10 companies, 2012-2017)

\begin{tabular}{|c|c|c|c|c|c|}
\hline $\begin{array}{l}\text { Stock } \\
\text { Code }\end{array}$ & Company & Positive & Negative & Neutral & $\begin{array}{c}\text { Overall } \\
\text { Sentiment }\end{array}$ \\
\hline 6599 & $\begin{array}{l}\text { AEON Co. } \\
\text { (M) Berhad }\end{array}$ & 0 & 0 & 178 & $\begin{array}{l}\text { Neutral } \\
(50 \%)\end{array}$ \\
\hline 5218 & $\begin{array}{c}\text { Sapura Energy } \\
\text { Berhad }\end{array}$ & 4 & 0 & 25 & $\begin{array}{l}\text { Neutral } \\
(50 \%)\end{array}$ \\
\hline 4197 & $\begin{array}{c}\text { SIME Darby } \\
\text { Berhad }\end{array}$ & 6 & 11 & 174 & $\begin{array}{l}\text { Neutral } \\
(50 \%)\end{array}$ \\
\hline 6742 & $\begin{array}{c}\text { YTL Power } \\
\text { International } \\
\text { Berhad }\end{array}$ & 0 & 0 & 37 & $\begin{array}{l}\text { Neutral } \\
(50 \%)\end{array}$ \\
\hline 5209 & $\begin{array}{l}\text { Gas Malaysia } \\
\text { Berhad }\end{array}$ & 0 & 0 & 194 & $\begin{array}{l}\text { Neutral } \\
(50 \%)\end{array}$ \\
\hline 7048 & $\begin{array}{l}\text { Atlan Hold- } \\
\text { ings Bhd. }\end{array}$ & 11 & 0 & 104 & $\begin{array}{l}\text { Neutral } \\
(50 \%)\end{array}$ \\
\hline 3395 & $\begin{array}{l}\text { Berjaya Co. } \\
\text { Bhd. }\end{array}$ & 3 & 0 & 80 & $\begin{array}{l}\text { Neutral } \\
(50 \%)\end{array}$ \\
\hline 4634 & $\begin{array}{l}\text { POS Malaysia } \\
\text { Bhd. }\end{array}$ & 1 & 0 & 194 & $\begin{array}{l}\text { Neutral } \\
(50 \%)\end{array}$ \\
\hline 5099 & $\begin{array}{c}\text { AirAsia Group } \\
\text { Bhd. }\end{array}$ & 1 & 0 & 73 & $\begin{array}{l}\text { Neutral } \\
(50 \%)\end{array}$ \\
\hline 6399 & $\begin{array}{l}\text { Astro Malay- } \\
\text { sia Holdings } \\
\text { Bhd. }\end{array}$ & 8 & 2 & 322 & $\begin{array}{c}\text { Neutral } \\
(50 \%)\end{array}$ \\
\hline
\end{tabular}

Table 10: Overall sentiment analysis for the three periods: Between announcement date to Ex-date, Ex-date to entitlement date, entitlement date to payment date (10 companies)

\begin{tabular}{|c|c|c|c|c|}
\hline $\begin{array}{l}\text { Stock } \\
\text { Code }\end{array}$ & Company & $\begin{array}{l}\text { Announcement } \\
\text { Date to Ex- } \\
\text { Date }\end{array}$ & $\begin{array}{c}\text { Ex-Date to } \\
\text { Entitlement } \\
\text { Date }\end{array}$ & $\begin{array}{c}\text { Entitlement } \\
\text { Date to } \\
\text { Payment } \\
\text { Date }\end{array}$ \\
\hline 6599 & $\begin{array}{l}\text { AEON Co. } \\
\text { (M) Berhad }\end{array}$ & Neutral $(50 \%)$ & $\begin{array}{l}\text { Neutral } \\
(50 \%)\end{array}$ & $\begin{array}{l}\text { Neutral } \\
(50 \%)\end{array}$ \\
\hline 5218 & $\begin{array}{l}\text { Sapura Ener- } \\
\text { gy Berhad }\end{array}$ & Neutral (50\%) & $\begin{array}{l}\text { Neutral } \\
(50 \%)\end{array}$ & $\begin{array}{l}\text { Neutral } \\
(50 \%)\end{array}$ \\
\hline 4197 & $\begin{array}{c}\text { SIME Darby } \\
\text { Berhad }\end{array}$ & Neutral $(50 \%)$ & $\begin{array}{c}\text { Neutral } \\
(50 \%)\end{array}$ & $\begin{array}{c}\text { Neutral } \\
(50 \%)\end{array}$ \\
\hline 6742 & $\begin{array}{c}\text { YTL Power } \\
\text { International } \\
\text { Berhad }\end{array}$ & Neutral (50\%) & $\begin{array}{l}\text { Neutral } \\
(50 \%)\end{array}$ & $\begin{array}{l}\text { Neutral } \\
(50 \%)\end{array}$ \\
\hline 5209 & $\begin{array}{c}\text { Gas Malaysia } \\
\text { Berhad }\end{array}$ & Neutral $(50 \%)$ & $\begin{array}{l}\text { Neutral } \\
(50 \%)\end{array}$ & $\begin{array}{l}\text { Neutral } \\
(50 \%)\end{array}$ \\
\hline 7048 & $\begin{array}{l}\text { Atlan Hold- } \\
\text { ings Bhd. }\end{array}$ & Neutral (50\%) & $\begin{array}{l}\text { Neutral } \\
(50 \%)\end{array}$ & $\begin{array}{l}\text { Neutral } \\
(50 \%)\end{array}$ \\
\hline 3395 & $\begin{array}{c}\text { Berjaya Co. } \\
\text { Bhd. }\end{array}$ & Neutral $(50 \%)$ & $\begin{array}{l}\text { Neutral } \\
(50 \%)\end{array}$ & $\begin{array}{l}\text { Neutral } \\
(50 \%)\end{array}$ \\
\hline 4634 & $\begin{array}{l}\text { POS Malay- } \\
\text { sia Bhd. }\end{array}$ & Neutral $(50 \%)$ & $\begin{array}{l}\text { Neutral } \\
(50 \%)\end{array}$ & $\begin{array}{l}\text { Neutral } \\
(50 \%)\end{array}$ \\
\hline 5099 & $\begin{array}{c}\text { AirAsia } \\
\text { Group Bhd. }\end{array}$ & Neutral $(50 \%)$ & $\begin{array}{l}\text { Neutral } \\
(50 \%)\end{array}$ & $\begin{array}{l}\text { Neutral } \\
(50 \%)\end{array}$ \\
\hline 6399 & $\begin{array}{l}\text { Astro Malay- } \\
\text { sia Holdings }\end{array}$ & Neutral $(50 \%)$ & $\begin{array}{l}\text { Neutral } \\
(50 \%)\end{array}$ & $\begin{array}{l}\text { Neutral } \\
(50 \%)\end{array}$ \\
\hline
\end{tabular}




\begin{tabular}{|c|c|c|c|c|}
\hline $\begin{array}{c}\text { Stock } \\
\text { Code }\end{array}$ & Company & $\begin{array}{c}\text { Announcement } \\
\text { Date to Ex- } \\
\text { Date }\end{array}$ & $\begin{array}{c}\text { Ex-Date to } \\
\text { Entitlement } \\
\text { Date }\end{array}$ & $\begin{array}{c}\text { Entitlement } \\
\text { Date to } \\
\text { Payment } \\
\text { Date }\end{array}$ \\
\hline & Bhd. & & & \\
\hline
\end{tabular}

The overall results for the 10 selected companies of the Trading/Services sector over a period of six years (2012 to 2017) for the dividend period, shown that the news analyzed using Azure Text Analytics produced more "Neutral" sentiment news and announcements. Some news and announcements showed Positive or Negative sentiment, but they did not affect the daily market price. The market movement was still within the range that was set at the benchmark. These results imply that shareholders and traders should not merely follow the company news and announcements to guide them in trading (buying and selling). They should also consider a second parameter to improve accuracy in decisionmaking during the buying and selling of stocks, for example, performing technical analysis in order to find a pattern in the stock chart to determine the market trend.

\section{Conclusion}

This paper presents a study and its findings on the relationship between news and announcement sentiment and the stock price, where positive sentiment will drive the company stock price and negative sentiment will lead to a downward market movement. Azure Text Analytics - which applies Natural Language Processing - was used to analyse the sentiment of company news and announcements retrieved from the Bursa Malaysia Website and The Edge Market. Ten companies from the trading/services sector were selected for the study. The results for the dividend period for 2012-2017, shown that the impact of news sentiment on market price was almost null - whereby it did not show any upward or downward market movement. The effect of negative sentiment was observed in the Sime Darby dividend period for 2013 - the negative sentiment accumulated over the dividend period was more than the positive sentiment.

There are a few limitations and challenges which affect the accuracy of this study. These include: limited and reliable sources to retrieve a company news and announcements; some important company news or announcements could have been overlooked and not captured for analysis. Furthermore, due to time constraint, only 10 companies from the Trading/Services sector were considered in the news sentiment analysis; incomplete list of 'stop words' for the text preprocessing process; and the duration of the dividend period from 2012-2017 (six years only) might not be long enough to produce accurate results. Hence, more efforts are needed in these aspects to improve the accuracy of this study. This can certainly help the traders in making more accurate decision in share market trading.

\section{Acknowledgement}

The authors would like to express their gratitude to the University of Malaya for the BKS research grant (Project No.: BKS0932017) to support this study.

\section{References}

[1] Investopedia. Dividend payment procedures. 2017, https://www.investopedia.com/exam-guide/cfa-level-1/corporatefinance/dividend-payment-procedures.asp.

[2] Feuerriegel S, Neumann D. Evaluation of news-based trading strategies. Lecture Notes in Business Information Processing Enterprise Applications and Services in the Finance Industry, 2015, pp. 13-28.

[3] Yusof Y. Ismail S. Determinants of dividend policy of public listed companies in Malaysia. Review of International Business and Strategy, 2016, 26(1):88-99.
[4] Suwanna T. Impact of dividend announcement on stock return. Proceedings of the International (Spring) Conference on Asia Pacific Business Innovation and Technology Management, 2012, pp. 721-725.

[5] Naren J, Sangavi R, Revathy S, Srimathi V. News analytics and dual sentiment analysis for stock market prediction. Proceedings of the $2^{\text {nd }}$ International Conference on Inventive Computation Technologies, 2017, pp. 132-137.

[6] Liang-Chih Y, Jheh-Long W, Pei-Chann C, Hsuan-Shou C. Using a contextual entropy model to expand emotion words and their intensity for the sentiment classification of stock market news. Knowledge-Based Systems, 2013, 41:89-97.

[7] Pagolu V, Challa K, Panda G, Majhi B. Sentiment analysis of Twitter data for predicting stock market movements. Proceedings of the IEEE International Conference on Signal Processing, Communication, Power and Embedded System, 2016, pp. 1345-1350.

[8] Li X, Xie H, Chen L, Wang J, Deng X. News impact on stock price return via sentiment analysis. Knowledge-Based Systems, 2014, 69:14-23.

[9] Hu M, Liu B. Mining and summarizing customer reviews. Proceedings of the ACM SIGKDD International Conference on Knowledge Discovery and Data Mining, 2004, pp. 168-177.

[10] Siah KW, Myers PD. Stock market prediction through technical and public sentiment analysis. 2015. http://kienwei.mit.edu/sites/default/files/images/stock-marketprediction.pdf.

[11] Li H, Pan SJ, Jin O, Yang Q, Zhu X. Cross-domain co-extraction of sentiment and topic lexicons. Proceedings of the $50^{\text {th }}$ Annual Meeting of the Association for Computational Linguistics, 2012, pp. 410-419.

[12] He Y, Lim C, Alani H. Automatically extracting polarity-bearing topics for cross domain sentiment classification. Proceedings of the 49th Annual Meeting of the Association for Computational Linguistics: Human Language Technologies. 2011, pp. 123-131.

[13] Parsehub. Leveraging data scraping for commercial due diligence. 2016, https://www.parsehub.com/blog/leveraging-data-scrapingfor-commercial-due-diligence/.

[14] Folger J. Stock-picking strategies: Fundamental analysis. 2018, https://www.investopedia.com/university/stockpicking/stockpickin g1.asp.

[15] Steen H, Ericson G, Wells J. How to detect sentiment analysis in text analytics. 2017, https://docs.microsoft.com/enus/azure/cognitive-services/text-analytics/how-tos/text-analyticshow-to-sentiment-analysis

[16] StockSnips. Stock news sentiment vs stock price. 2017, https://stocksnips.net/materials/stock-news-sentiment-vs-stockprice/.

[17] Mokhtar SH, Nassir AM, Hassan T. Detecting rational speculative bubbles in the Malaysian stock market. International Research Journal of Finance and Economics, 2006, 6:102-115. 